\title{
Editorial
}

\section{New partnerships in publishing and politics}

http://dx.doi.org/10.17159/2413-3108/2016/i56a1288

We are very pleased to announce that the Institute for Security Studies (ISS) has partnered with the University of Cape Town (UCT) as co-custodians of the South African Crime Quarterly (SACQ). We believe that the UCT Centre of Criminology's commitment to advancing policy-relevant research and analysis on public safety, criminal justice and evolving forms of crime in South Africa, and the global South more broadly, complements the SACQ's objective of contributing balance and objectivity to the discourse on human security in Africa. Both institutions are committed to ensuring that $S A C Q$ remains an accessible source of up-to-date research and analysis that is policy relevant.

Since January this year we (SACQ editor and ISS senior research fellow, Chandré Gould, and UCT senior researcher and SACQ editor, Andrew Faull) have been working together to prepare for this moment. Our close collaboration will carry through to the end of the year, at which point the bulk of editorial responsibilities will shift to Andrew and UCT.

It has been a rocky first six months of 2016 for South Africa since December 2015, when President Jacob Zuma announced the surprise dismissal of the country's market-trusted finance minister, Nhlanhla Nene, and replaced him with a relatively unknown member of Parliament, Des van Rooyen. Overnight the country's stocks and bonds lost half a trillion rand in value. Investors and citizens feared the move was an attempt by the president to increase his access to the country's treasury, fears that were reinforced when the Deputy Minister of Finance, Mcebisi Jonas, and former ANC MP Vytjie Mentor publicly claimed they had been offered ministerial positions by the powerful Gupta family, who are known to be close to the president. The turbulence of what became known as 'Nenegate' was somewhat steadied when Zuma, under pressure from multiple fronts, retracted his decision and appointed former finance minister, Pravin Gordhan, to replace Van Rooyen. Yet, as we write, Gordhan's future hangs in the balance. He is under investigation by the Hawks for allegedly authorising a unit of the South African Revenue Service to spy on politicians.

In February, the Constitutional Court found that Zuma had failed to uphold and respect the Constitution by ignoring the public protector's 2014 finding that he unduly benefitted from tax-funded upgrades to his private residence. Zuma and the ANC had previously worked hard to deflect criticism and deny accountability for the matter. Despite the court's finding, at the time of writing the South African public was no closer to knowing whether the president would indeed capitulate to the court's injunction and 'pay back the money'.

In April, the president was in the public spotlight again when a full bench of the North Gauteng High Court ruled that the 2009 decision by former National Prosecuting Authority (NPA) head Mokotedi Mpshe not to prosecute Zuma for corruption was irrational, and should be revisited. However, in May, National Director of Public Prosecutions Shaun Abrahams announced that the NPA would appeal the court's decision, despite legal commentators hinting that the appeal had little chance of success. Thus, in this case too, resolution or closure appears to be a long way off.

These high-profile events, along with disruptions and conflict in Parliament, have served to create a political landscape that is both uncertain and troubling ahead of the local government elections planned for August 
this year. Political uncertainty has impacted significantly on South Africa's economic growth forecasts, and for working class and unemployed South Africans the immediate future seems bleak. Moreover, criminal justice institutions - the Hawks and the NPA in particular - are deeply embroiled in these political machinations, raising questions about their ability to serve the interests of citizens without political interference.

On a far more positive note, the acting head of the South African Police Service (SAPS), career policeman Lieutenant-General Khomotso KJ Phahlane, has brought a semblance of stability to the SAPS and opened the door to increased collaboration with civil society to address the challenges facing policing. The SAPS also recently established a research unit, hinting at a new appreciation for the kinds of knowledge we aim to promote through SACQ.

In this issue of SACQ we revisit some of the key intersections of daily crime, violence and justice in South Africa's most precarious localities and among its most vulnerable groups. We begin with an article by Heidi Mogstad, Dominique Dryding and Olivia Fiorotto that explores the challenges and limitations of policing domestic violence in Khayelitsha. The article is based on data gathered through focus groups with men and women, conducted during the Khayelitsha Commission of Inquiry. Perhaps one of the most significant contributions of this article is to show that women who hold status in their community are reluctant to be identified as victims, and thus are disinclined to report intimate partner violence, because this undermines their standing and status. This calls into question the continued framing of women as victims in public discourse and policy.

Continuing the focus on gender, Carolyn Agboola's article reports on interviews with women who had been released from correctional facilities. She documents their claims of poor health care, sanitation, food, access to education and overcrowding in the female sections of the facilities in which they were incarcerated.

Lizette Lancaster and Ellen Kamman's article explores the hypothesis that risk of murder is associated with particular demographic and contextual characteristics. Police crime data, as currently presented, make it very difficult to understand actual risk across different police precincts. The authors propose an innovative and promising method of analysis through which researchers can accurately make sense of police precinct-level crime data in relation to municipal and small area boundaries, and related population data.

In Jamil Mujuzi's article, attention shifts to private prosecutions in Zimbabwe. The article explores recent changes to the country's Criminal Procedure and Evidence Act, and asks whether there are instances where the prosecutor-general is compelled to issue certificates to victims of crime that would allow them to pursue private prosecutions. Mujuzi points out that the related Zimbabwean case law may be of interest in South Africa, where juristic persons have argued that laws prohibiting private prosecutions are discriminatory and unconstitutional.

Finally, in the 'On the Record' feature, we return to Khayelitsha, where Andrew Faull interviewed the Social Justice Coalition General Secretary, Phumeza Mlungwana, about crime and policing in the area, and about the organisation's motivation for launching a court case against the SAPS.

We hope you enjoy the read.

\section{Chandré Gould and Andrew Faull (Editors)}

